\title{
Technological convergence in the IT industry: the role of strategic technology alliances and technological competencies
}

Citation for published version (APA):

Duysters, G. M., \& Hagedoorn, J. (1997). Technological convergence in the IT industry: the role of strategic technology alliances and technological competencies. MERIT, Maastricht Economic Research Institute on Innovation and Technology. MERIT Research Memoranda No. 010 https://doi.org/10.26481/umamer.1997010

Document status and date:

Published: 01/01/1997

DOI:

10.26481/umamer.1997010

Document Version:

Publisher's PDF, also known as Version of record

\section{Please check the document version of this publication:}

- A submitted manuscript is the version of the article upon submission and before peer-review. There can be important differences between the submitted version and the official published version of record.

People interested in the research are advised to contact the author for the final version of the publication, or visit the DOI to the publisher's website.

- The final author version and the galley proof are versions of the publication after peer review.

- The final published version features the final layout of the paper including the volume, issue and page numbers.

Link to publication

\footnotetext{
General rights rights.

- You may freely distribute the URL identifying the publication in the public portal. please follow below link for the End User Agreement:

www.umlib.nl/taverne-license

Take down policy

If you believe that this document breaches copyright please contact us at:

repository@maastrichtuniversity.nl

providing details and we will investigate your claim.
}

Copyright and moral rights for the publications made accessible in the public portal are retained by the authors and/or other copyright owners and it is a condition of accessing publications that users recognise and abide by the legal requirements associated with these

- Users may download and print one copy of any publication from the public portal for the purpose of private study or research.

- You may not further distribute the material or use it for any profit-making activity or commercial gain

If the publication is distributed under the terms of Article $25 \mathrm{fa}$ of the Dutch Copyright Act, indicated by the "Taverne" license above, 


\section{Technological convergence in the IT industry: the role of strategic technology alliances and technological competencies}

Geert Duysters and John Hagedoorn*

August 1997

Draft

* The contribution to this paper by John Hagedoorn was done while visiting the Center for International Science and Technology Policy Studies at George Washington University, Washington (DC). This research was partly funded by the US National Science Foundation.

MERIT, Faculty of Economics and Business Administration, Maastricht University, P.O. Box 616, 6200 MD Maastricht (Netherlands) - telephone (31)43-3883897- fax: (31)433254566 


\section{INTRODUCTION}

For a long time technological developments in telecommunications and computers have followed very distinct trajectories. Today, the basic design parameters which form the core of technological regimes (Georghiou, et al. 1986) are increasingly becoming more similar, not only in terms of the material properties but also with respect to the manufacturing process involved. Although the first signs of the convergence process became apparent in the late 1950s it was not until the early 1970s that it really took off. At that time large numbers of powerful digital components were brought onto the market at relatively low costs. In the following years subsequent improvements accelerated the rate of adoption of these components in all kinds of electronic equipment. Today almost every single electronic device is based on the same digital technology. Digitalization of telecommunications and computer equipment has broadened the existing technology base and facilitated the emergence of large-scale communication networks that carry voice, data and images. As computers were increasingly accommodated within those telecommunications networks, previously existing technological and market boundaries became vague. The blurring boundaries between the computer and telecommunications markets soon challenged the core competencies of the traditional suppliers and induced some 'lateral entry': i.e. entrance of firms from adjacent markets. In the telecommunications industry the first signs of convergence appeared through the introduction of stored program control (SPC) in the field of digital switching. ${ }^{1}$

The second wave of convergence took place during the mid-1980s when analogue telephone systems were gradually transformed into fully digital networks (Davies, 1991). 
The rise in distributed computing and the digitalization of the telecommunications network induced a number of telecommunication firms to accumulate skills in software and micro-electronics and raised the interests of computer manufacturers in telecommunication technology. At that time a number of authors and industry practitioners argued that the information technology (IT) industry would eventually offer a continuum of products, which could not be referred to as either telecommunication or computer products. They envisioned that all the different IT markets would melt into one giant 'information and entertainment industry' and that firms would react to the new opportunities by lateral entry into each other's markets (de Jonquieres, 1989; Business Week, 25 May 1992, pp. 69-71).

The relatively stable environment that characterized the computer industry and more in particular the telecommunications industry for such a long period, before the changes mentioned above occurred, induced firms to develop a stable set of routines to deal with their environment. Today such routinized behaviour does not seem sufficient to deal with the technological convergence process in information technologies. The required technological competencies in adjacent technologies is often not present within the existing technology base. For companies lacking such competencies, several options are open to acquire the essential technological knowledge. Technology can be developed in-house or it can be acquired on the market by arms'-length transactions (e.g. using R\&D contracts) or through the acquisition of technologically sophisticated companies. Between these two extremes, acquisition or internal development, several options are open to a company. Companies may perform $R \& D$ together with a partner, license-in 
technology or use other forms of cooperation. Internal development is costly but often necessary to achieve the required technological base. Cooperative strategies, on the other hand, involve less capital and are particularly suited to monitor new technological developments. In the past decade the number of strategic alliances made by firms has increased substantially, in particular in high-tech industries (see Hagedoorn, 1996). The use of alliances, however, often appears only effective in combination with internal development. Haklisch (1989) has argued convincingly that interdependence is often used as a viable strategy to strengthen independence.

The instabilities hat are part of the changes mentioned in the above made many industry observers in the early 1980's expect that the convergence process would provoke a battle between the industry giants IBM and AT\&T (Tunstall, 1986). After its break-up in 1984, AT\&T was allowed to enter other (unregulated) markets and it acquired companies such as MOS Technology and NCR. IBM on the other hand grasped the opportunity to strengthen its presence in the telecommunications market and bought telecom equipment makers Rolm Corporation and SBS Satellite. AT\&T turned its focus on the computer industry by acquiring a stake in Olivetti. Although acquisition of knowledgeable companies seems to be an attractive option for companies that have to deal with convergent technologies, acquisition strategies are hampered by at least three main problems (Aldrich and Auster, 1986). The first problem is associated with information distortion and opportunism, which may mislead the acquiring company. A second problem is that creative and innovative companies which are incorporated in a large and bureaucratic structure often lose their flexibility and therefore lose much of 
their original creativity and innovativeness. The third problem is related to the externalities which are connected to the acquisition of a company. It is often difficult to divest those assets which were not sought for in the first place. An additional problem that is associated with acquisitions occurs if a company does not have an already sufficiently developed level of technological knowledge in a specific field. Then it turns out to be extremely difficult to absorb the acquired knowledge into its own technological core. It is often noted that a firm's absorptive capability is to a large degree dependent on the degree of knowledge in a specific field (Dodgson, 1989; Cohen and Levinthal, 1990; Levinthal, 1994). Therefore we might argue that if the core of a company's technology base is not sufficiently adapted to the new technology, then the absorption of acquired technological knowledge within the technological core of a company is very difficult. These factors may explain why most of the acquisitions were (until today) not very successful. In the late 1980's IBM moved out of telecommunications by selling its share in Rolm, whereas a large number of telecommunications companies sold their interests in computer equipment (Malerba et al, 1991). In the early 1990's, it gradually became clear that the expected 'lateral entry' between the telecommunications and computer markets had not taken place (Mansell, 1993). Two factors seemed to be responsible for the low degree of lateral entry that was found in the telecommunications and computer markets, i.e. economies of scope that turned out to be lower than expected and the continuing importance of scale economies (Malerba et al, 1991). Economies of scope which were gained by the joint production of telecommunication and computer equipment were simply not able to offset the loss of economies of scale. In this paper we 
argue that there is a third, maybe even more important, factor that influenced the low degree of convergence within firms, namely inertia. Following evolutionary and ecological theory we will argue that both external and internal inertial forces significantly reduce the ability of firms to deal with changes in their technological cores. Firms are often simply not able to adapt swiftly to their changing technological environments.

Against this general background of the process of technological convergence, our current contribution will pay attention to two topics. One topic deals with the question to what extent the convergence of telecommunications and computer technologies has affected a similar degree of convergence in the technological capabilities of individual companies operating in different fields. Or to put it differently, one of the aims of this paper is to examine whether the convergence of information and communication technologies has led to a growing sectoral similarity of firms that were originally active in different IT markets. The second topic concerns the relevance of strategic alliances as companies from different industries and technological fields combine their efforts as part of a concrete process of technological convergence.

\section{RESEARCH TOPICS AND HYPOTHESES}

Patterns of convergence are generally thought to occur at a number of different levels: the product-market level, the technology level and the firm level (von Tunzelmann, 1988). At the product-market level we find well-known examples of the convergence in IT such as 'tele-matics' products, which embody the convergence between computer and telecommunications technology. At the technology level we find a change away from 
analogue devices towards completely digital devices as virtually all segments of the IT industry are affected by the pervasive effect of micro-electronics technology and software. In this paper the emphasis shifts towards the level of the firms. In that context we examine whether and to what degree firms from different markets are affected by the process of technological convergence.

Although telecommunications and computer equipment are based on the same enabling technologies, it can be argued that the convergence process has taken place much more slowly than was expected in the early 1980s (Malerba et al., 1991; von Tunzelmann and Soete, 1987; von Tunzelmann, 1988). The few empirical studies on the convergence process within firms (von Tunzelmann and Soete, 1987, von Tunzelmann, 1988) showed that patterns of convergence had not significantly affected the core competencies of the major IT firms. ${ }^{2}$ These analyses were based on US patent data which covered the periods 1969-1984 and 1969-1986. Most industry observers and practitioners agree, however, that the convergence process accelerated in the late 1980s and early 1990s. ${ }^{3}$ Therefore an analysis that is based on data until 1986 is likely to underestimate the current magnitude and importance of the convergence process. Extending the time-frame might therefore be an important step forwards in understanding the broader implications of these patterns of convergence in IT markets.

In the following analysis of this process of convergence, we not necessarily witness companies as being rapid, flexible adapters. We much more stress the importance of inertial forces that prevent organizations from quickly transforming their strategies and structures according to new demands of the environment. Following evolutionary 
theorists, we argue that apart from a stochastic element in the choice of decisions and their outcomes, most of the behaviour of firms is relatively predictable and repetitive. Such standard patterns of behaviour are often labelled 'routines' (Nelson and Winter, 1982) or 'comps' (McKelvey, 1982). These routines can be compared to biological genes because they govern a firm's behaviour and are heritable in the sense that future behaviour is largely based on today's characteristics (Nelson and Winter, 1982). A firm's reliance on basic routines severely reduces its speed of adaptation. However, it would also be a caricature to perceive firms only as static organizations that are unable to change. Firms can be engaged in a 'search' process in an attempt to increase their 'fit' with the environment. Yet, change mechanisms are mainly triggered if the performance of an organization is well below its aspiration level (Cyert and March, 1963; Lant and Mezias, 1992). Firms with a relatively successful past are therefore often even more resistant to change than other firms. This so-called 'success breeds failure syndrome' (Starbuck, et al., 1978) is frequently observed with established industry leaders. Evolutionary theorists argue that firms which are engaged in a search process do not explore all possible directions but confine their search to the most promising directions. Firms are often engaged in 'local search' only, which means that search is limited to related areas. Local search and a continued reliance on their basic routines implies that firms are much better in doing more of the same than they are in adapting to change. We therefore expect that companies mainly stick to their core businesses and therefore patterns of convergence are not likely to be found as the most dominant features of changes within companies. Thus: 
Hypothesis 1: $\quad$ Patterns of technological and product-market convergence have not significantly affected the technological cores of the participating companies.

Existing empirical studies on the convergence process do not seem to study strategic alliance as such, but von Tunzelmann (1988) suggests that “... various 'stopgap' arrangements like strategic alliances were being sought to grapple with circumstances where this was proving a major competitive liability...” (von Tunzelmann, 1988, p.3). Because of surging R\&D costs in combination with shrinking life cycles in all IT segments, firms are no longer able to monitor all the technological developments in the IT industry. Therefore, access to knowledge from other players in adjacent markets is becoming increasingly important (Economic Commission for Europe, 1987; Korzeniowski, 1988). The convergence process causes the blurring of traditional technological and sectoral boundaries and therefore increases the need for companies to keep up with many different technologies (van Tulder and Junne, 1988). Broadening the existing technology base through internal development would call for a considerable increase of the already heavy $R \& D$ cost burden. The combination of rising $R \& D$ costs and shorter life cycles induces firms to search for alternatives to internal development as the sole means of developing new capabilities. Cooperation is often considered as a viable means to monitor several technological developments at relatively low cost. Given the problems with acquisitions as noted above, it therefore seems interesting to consider whether strategic technology alliances are increasingly used to deal with patterns of 
technological convergence (see van Tulder and Junne, 1988; Leban et al., 1989; Raphael, 1989; Charles et al., 1989). Therefore:

Hypothesis 2: $\quad$ Firms tend to converge by means of strategic technology alliances, in the sense that the number of strategic technology alliances in neighbouring sectors have increased significantly over time as compared to the alliances in 'core' sectors.

\section{DATA}

For our analysis we use two types of data: patent data and data on strategic technology alliances. The patent data is based on a database that is compiled by the European Patent Office (EPO), which was established in 1978 on behalf of 13 European countries. Inventors which desire the protection of their invention can apply to the EPO for a patent in one or more of the 13 associated countries. The use of patent statistics has been criticized on many different grounds (Cohen and Levin, 1989; Griliches, 1990; Archibugi, 1992). The first and probably most important criticism is related to the use of patents as a measure of innovative output. It is argued that firms differ considerably in their propensity to patent. Some firms consider patenting as a viable means of protecting their innovations whereas others make use of other methods to safeguard their technological improvements. There are also wide country-specific differences in the approach towards patenting. Japanese firms, for example, tend to patent every claim, whereas US companies are more likely to bundle several claims into one patent (see 
Cohen and Levin, 1989). The propensity to patent not only differs across firms but also across industry sectors.

Another problem of patent statistics is related to the large differences that exist in the economic and technological importance of individual patents. Although some patents can be associated with major technological breakthroughs, a far larger number of patents are of considerably less importance and many patents are not even commercially exploited (Dorfman, 1987; Graoutzi et al., 1988; Cohen and Levin, 1989). A related problem is that the majority of patents applied are for product improvements. Although process innovations are usually not less significant in both economic and technological terms they are often not patented. In the case of process innovations, secrecy often turns out to be a viable alternative to patenting. For process innovations lead time and learning curve advantages also seem to be sufficient to protect the innovation (Nelson, 1987; Dosi, 1988).

However, there are also a number of advantages of using patent statistics. One important advantage of patent data over innovation input data is that patents are assigned to different technology classes which in turn can be (partly) translated into different economic sectors (Pavitt, 1988; Acs and Audretsch, 1989). Another important factor is that the chances of a patent being granted are closely related to the technological sophistication of a product and its innovative features. We might therefore argue that patents are a relatively good indicator of the level of technological sophistication of a company (Nystrom and Edvardsson, 1980). We must, however, keep in mind that patent statistics can not be applied to measure the complete set of technological variables. Patent 
statistics can only measure the codifiable part of technology, they cannot be used to measure tacit elements of technology.

In the present analysis patent statistics will be used to measure changes in the technological cores of major IT companies. In order to guarantee the 'global' character of our sample we incorporated all the leading companies in each sector: i.e. computers, telecommunications and semiconductors. ${ }^{4}$ We deliberately did not assign companies to a certain sectoral category on the basis of their profile but on the basis of their sales level in a specific sector. That means that we did not a priori label companies as being either computer firms, telecommunications firms or semiconductor firms according to their past or present profile. If we had only included firms that fit a certain profile we would not have accounted for the convergence that existed at the beginning of the time period. Company-level aggregation of subsidiaries was performed for every year of the analysis. ${ }^{5}$ Information on company subsidiaries was taken from annual reports and from multiple volumes of ‘Who Owns Whom' (Dun and Bradstreet, 1970-1994). Company structures therefore differ with respect to the year in which they are analysed. Such an approach enables us to include also that part of the convergence which can be attributed to takeovers in adjacent markets. Changes in the technological cores of major IT-producing companies were measured by analysing the distribution of patents among three major IT sectors: computers, telecommunications and semiconductors. We assume that shifts in the core (technological) competencies of firms are reflected in changes in the relative number of patents that are applied for in a specific sector.

The data on strategic technology alliances were taken from MERIT's CATI- 
database (see Appendix II). The CATI-database contains information on over 10,000 agreements (of which some 5,000 agreements are related to the information technology sector). All the alliances in the database are either related to technology transfer or to some sort of joint innovative effort. We will use the term alliance to refer to those cooperative agreements that are not connected through majority ownership. An alliance can normally be seen as an agreement which is positioned between two extremes: arm'slength transactions on the market on the one hand and the complete merger of the two firms on the other. Our present study focuses on those alliances that were established in the period 1980-1993.

The CATI-database is somewhat biased in terms of:

- a skewness in the distribution of modes of organizations towards those that are more often reported in the literature

- a possible over-representation of large firms

- the underestimation of certain technology fields which do not belong to the core technologies

- a possible bias towards Anglo-Saxon organizations.

Our preoccupation with rather large companies and IT markets, however, implies that our analysis is unlikely to be seriously biased by these drawbacks.

Data on strategic technology alliances was used to measure the degree to which alliances are used to cope with the convergence process. As in the case of patents, we measured for each company the distribution of alliances among three major IT sectors: computers, telecommunications and semiconductors. In order to safeguard the strategic 
element in our sample we will study only those alliances which are undertaken for strategic reasons. Following Hagedoorn (1992) we will refer to alliances as being strategic if they can reasonably be assumed to affect the long-term product market positioning of at least one partner. Because alliances between government or academic institutions and private companies are frequently undertaken for different economic reasons than the alliances between two or more private companies ${ }^{6}$ (see e.g. Haklisch, 1986), we will restrict our attention to those alliances which are established between private companies. For the same reason we do not pay attention to government-initiated or EU-wide R\&D cost-sharing programmes such as ESPRIT, EUREKA or JESSI.

\section{ANALYSIS}

A first indicator of the degree of convergence within leading IT companies is the presence of companies in more than one table of leading companies (see appendix I). In our sample of leading IT manufacturers eight companies are among the leading producers of all three types of equipment: i.e. computers, telecommunications and semiconductors. With the exception of AT\&T (and IBM if one includes captive production) all those players have a European (Philips, Siemens) or Japanese background (Fujitsu, Hitachi, Matsushita, NEC, Toshiba). This is not remarkable because it is well known that Japanese and European multinationals have a more diversified character than their US counterparts. ${ }^{7}$

Figure 1 shows the distribution of patents of leading computer producing companies as a percentage of their combined number of patents in all three sectors. 
Convergence seems to be an essential feature of these firms ever since the early 1980 s. Involvement in telecommunications has always been very high and this high level of telecommunications patents turns out to be relatively stable over time. The data, however, indicate a decreasing trend of semiconductor patents in favour of computer patents.

insert Figure 1 about here

Figure 2 displays a more diffuse pattern. It shows the distribution of strategic technology alliances of leading computer companies. In general the percentages of alliances in the different sectors seem to be somewhat inversely related to the percentages of patents. Alliances related to computers seem to take an intermediate position, whereas semiconductor alliances account for a relatively large share of all alliances. Telecommunication alliances, on the other hand, seem to play a relatively modest role. The data does not indicate any significant trends except for a rise in semiconductor alliances during the period 1988-1990 and a corresponding decrease of computer and telecommunication alliances during the same period.

insert Figure 2 about here

In order to test our hypotheses we will now turn to a more quantitative approach. The first step in our analysis is to test hypothesis 1 , which states that ongoing patterns of technological and product-market convergence have not significantly affected the 
technological cores of the participating companies. We therefore assume that there is no positive relationship between time and relative sectoral patenting.

A simple linear regression is used to measure the correlation between time and the relative importance of patents and alliances in a particular sector (Table 1). We apply linear regression technique because we expect a linear relationship between patenting behaviour and time and also because the graphs that are presented above do not indicate a non-linear pattern. Because we assume that the number of patents or alliances in one period could be related to the number of patents in the immediate preceding periods we tested the results for autocorrelation. In only one case (telecommunication patents for semiconductor firms) we did find autocorrelation to exist (Durbin Watson: 0.93880). We therefore decided to use an autoregression analysis for that particular case in order to correct the results for autocorrelation.

insert Table 1 about here

The overall measure of goodness of fit for the linear model is represented by the coefficient of determination $\left(\mathrm{R}^{2}\right)$. High $\mathrm{R}$ squares are found for computer patents and semiconductor patents. R squares for all the other variables are very low. In the case of computer patents almost 60 per cent of the variance is accounted for by the regression, whereas in the case of semiconductor patents this figure is about 62 per cent. The $\mathrm{F}$ values that are used to test the significance of the $R^{2} s$ and for the significance of the dependent variable in the equation show that both computer patents and semiconductor 
patents are significantly dependent on the independent variable (time). The Beta for computer patents shows a positive sign whereas the Beta for semiconductor patents is represented by a negative sign. This implies that computer producing companies have significantly decreased their relative interest in semiconductors in favour of a growing number of patents in their 'core business'. These results indicate that hypothesis 1, which asserted that patterns of technological and product-market convergence have not significantly affected the technological cores of companies, can be confirmed for computer companies. For the relative distribution of strategic technology alliances we did not find any significant trends except for the constant in the equation which is significant for all cases. This indicates a strong stability in the relative distribution of alliances over time. It is therefore very unlikely that firms converge through means of strategic alliances as put forward by hypothesis 2 , at least in the analysis of leading computer companies. This means that hypothesis 2 cannot be confirmed on the basis of our analysis.

For leading telecommunication equipment companies we found quite a different pattern (see Figure 3). Convergence processes seem to have had only a modest impact on these companies. By far the largest number of technological activities measured by patents take place in the telecommunications field itself. Overall there seems to be only a slight interest in computer technology and a decline in the number of semiconductor patents. 
The distribution of strategic alliances as shown in Figure 4 shows a similar low degree of involvement in computer technology. Alliances in the field of semiconductors now account for a significantly larger share. The share of semiconductor alliances as a percentage of the total number of alliances, however, does not seem to be rising over time. Since the mid 1980's telecommunication alliances account for most of the IT alliances of telecommunications equipment producing companies.

insert Figure 4 about here

The results of the linear regression (Table 2) show relatively high $\mathrm{R}^{2} \mathrm{~s}$ for patents in telecommunications and semiconductors. Corresponding significance levels are 0.05 in the case of telecommunications patents and 0.01 in the case of semiconductor patents indicate major shifts in the distribution of patents among different technological sectors. The results of the analysis for computers, however, do not indicate a significant trend in the relative importance of computer patents for telecommunication equipment producing companies. Again we find a growth in the relative importance of 'core' telecommunications patents $(\mathrm{p}<0.05)$ and a significant decrease in the relative importance of semiconductor patents $(\mathrm{p}<0.001)$. This, again, confirms hypothesis 1 that convergence has not been able to change the relative importance of the core technological competencies.

------- insert Table 2 about here ------- 
The results for strategic alliances resemble the previous findings for alliances in the sense that they do not indicate a growing degree of convergence through strategic technology alliances. This indicates that hypothesis 2 can also not be confirmed by our analysis for telecommunications companies.

\section{CONCLUSIONS}

In the above we analysed how major computer and telecommunications equipment companies are affected by the technological convergence process. The results of the regression analyses have shown that firms are basically unaffected by technological convergence during the period 1980-93. The results indicate a confirmation of hypothesis 1 which argued that firms are still doing more of the same instead of being involved in a process of redefining their 'core' business. Hypothesis 2, which argued that firms tend to converge through means of strategic technology alliances, could not be confirmed on the basis of our analysis. In spite of a significant growth in the absolute number of alliances in all sectors, cooperative agreements do not seem to be used extensively for dealing with technological convergence. We may therefore conclude that technological convergence, although apparent on the technological and product/market level, does not seem to have affected the 'core' competencies of major IT companies. Firms seemed to have maintained their original technological base. According to Stinchcombe (1965), there are three reasons which can be responsible for the persistence of traditional forms. The first reason is that the original form is still the most efficient form. The second reason is that the original form may be pertained by institutional forces, 
vested interests or a strong ideological position. The third reason is based on the existence of a natural monopoly or an assured funding base. We believe that in today's deregulated and liberalized market structures, institutional forces are not strong enough to induce firms to take on a particular form. For manufacturing companies, the argument of a natural monopoly or assured funding base does not seem to be relevant any more. That means that it is very likely that for many organizations the original technological base is still seen as the most efficient. Despite the observed technological convergence we are therefore still able to discern different organizations that are recognizable as to their traditional base instead of one converged form where the difference between e.g. telecommunications and computer companies has become technologically almost irrelevant.

Aldrich (1979) has argued that different organizations can coexist only if they are dependent on different environmental resources. That means that although they are influenced by the same technological regime, companies operating in computers and telecommunications constitute different niches. It is remarkable to see that despite the noted general convergence at the start of the 1980's, both computer and telecommunications firms have retained most of their interest in their 'old' technological base, indicating no pattern of increased technological convergence within firms. The ongoing process of technological convergence at the product-market and the technology level has not been accompanied by a significant rise in the relative number of patents or alliances in adjacent technologies. From an evolutionary perspective such patterns of resistance to change are not unexpected. We think, however, that in the future companies 
will have to adjust their aspiration levels of technological performance given the potential of technological convergence in the IT industry. Therefore, we think that at that time companies will be forced to redefine their 'core' business and adapt their existing technology base according to the demands of the new technological regime. Strategic technology alliances in combination with internal development can be an important means to achieve that goal. Although at present strategic technology alliances do not seem to be extensively used to deal with the convergence process, we think that, given the rapid increase in the number of newly established strategic technology alliances, they can still play a very important role in changing high-tech sectors such as the IT industry. 
Figure 1 The sectoral distribution of patents of leading computer companies (three year moving averages, 1980-1993).

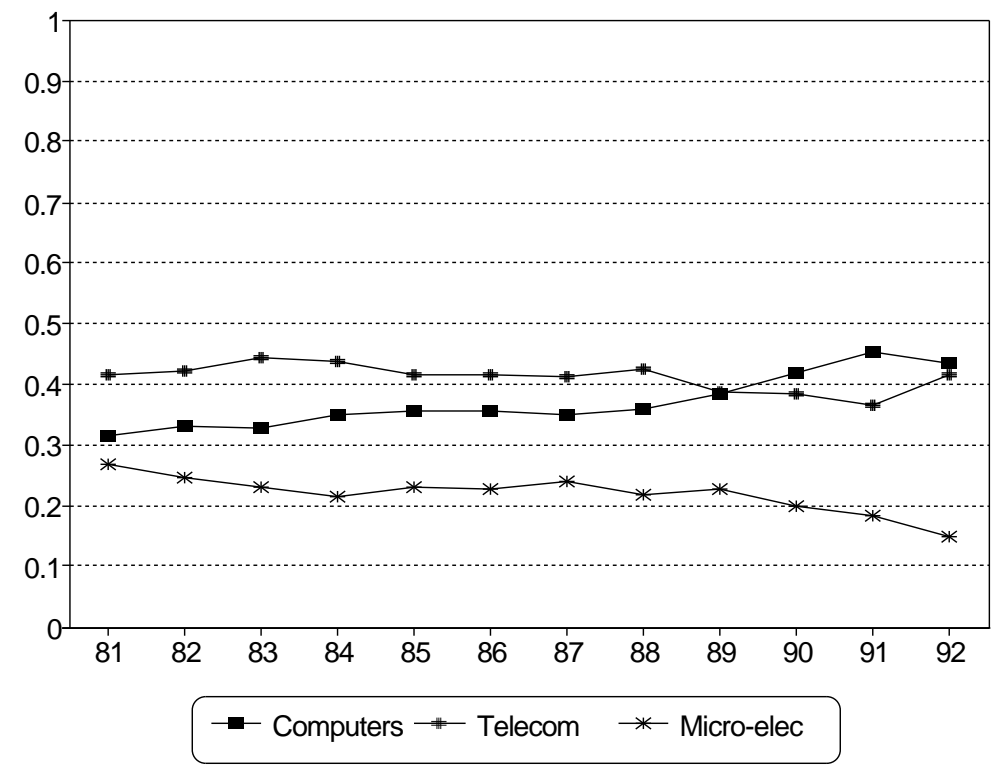

Figure 2 The sectoral distribution of strategic technology alliances of leading computer companies (three-year moving averages, 1980-1993).

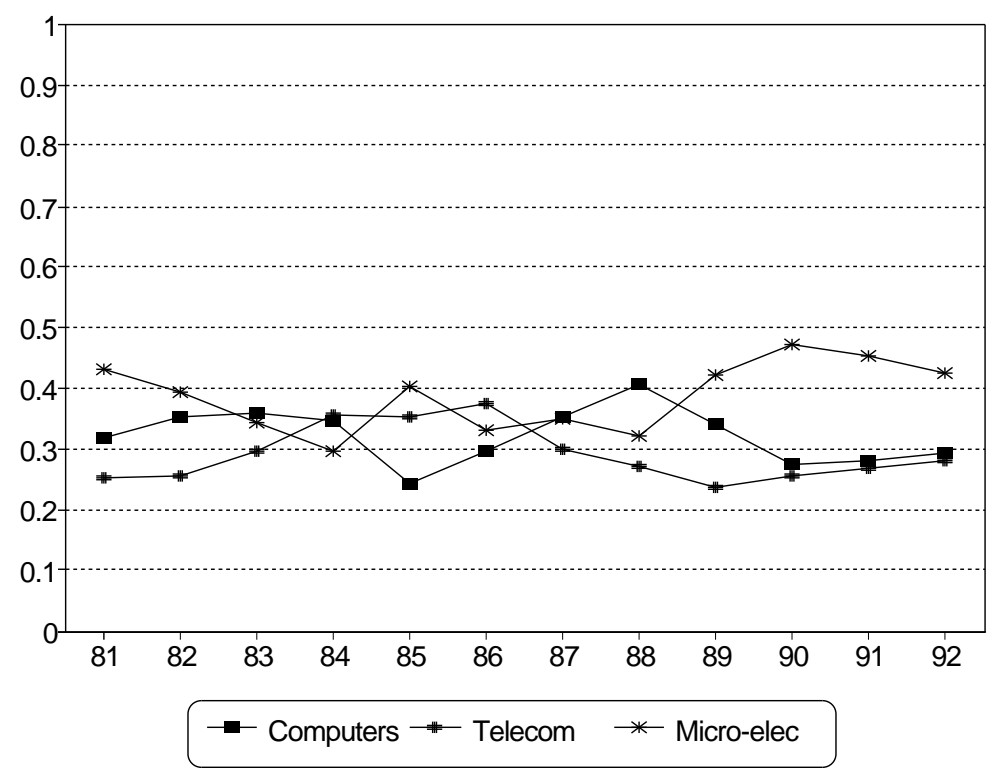


Figure 3 The sectoral distribution of patents of leading telecommunications equipment companies (three-year moving averages, 1980-1993).

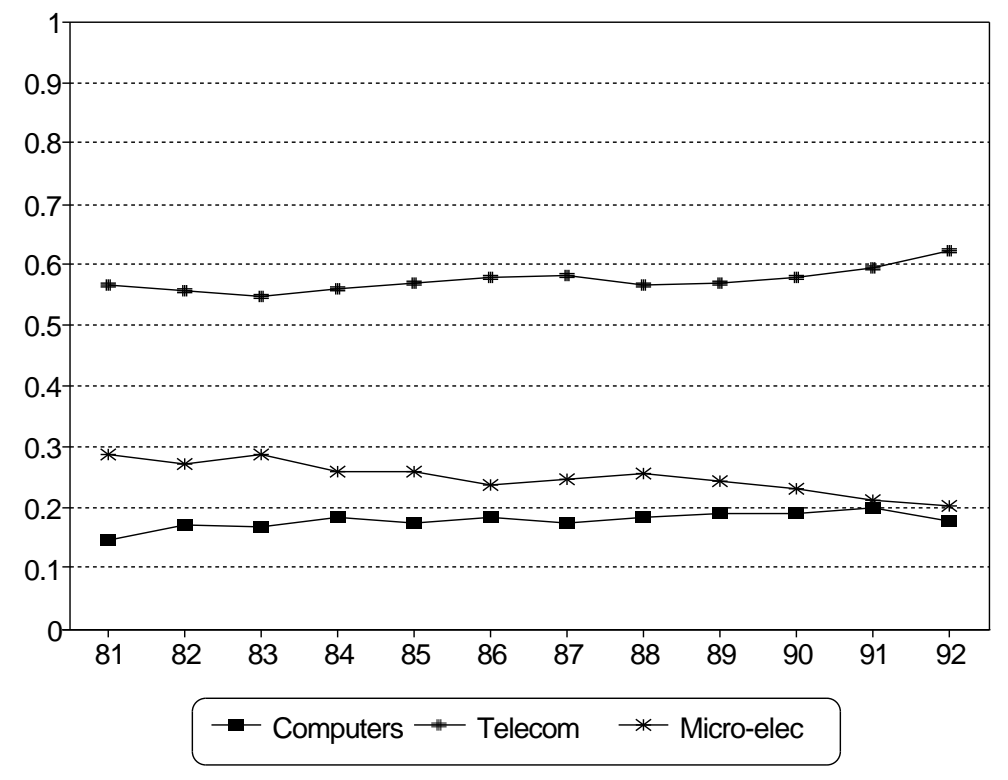

Figure 4 The sectoral distribution of strategic technology alliances of leading telecommunications equipment companies (three year moving averages, 1980-1993).

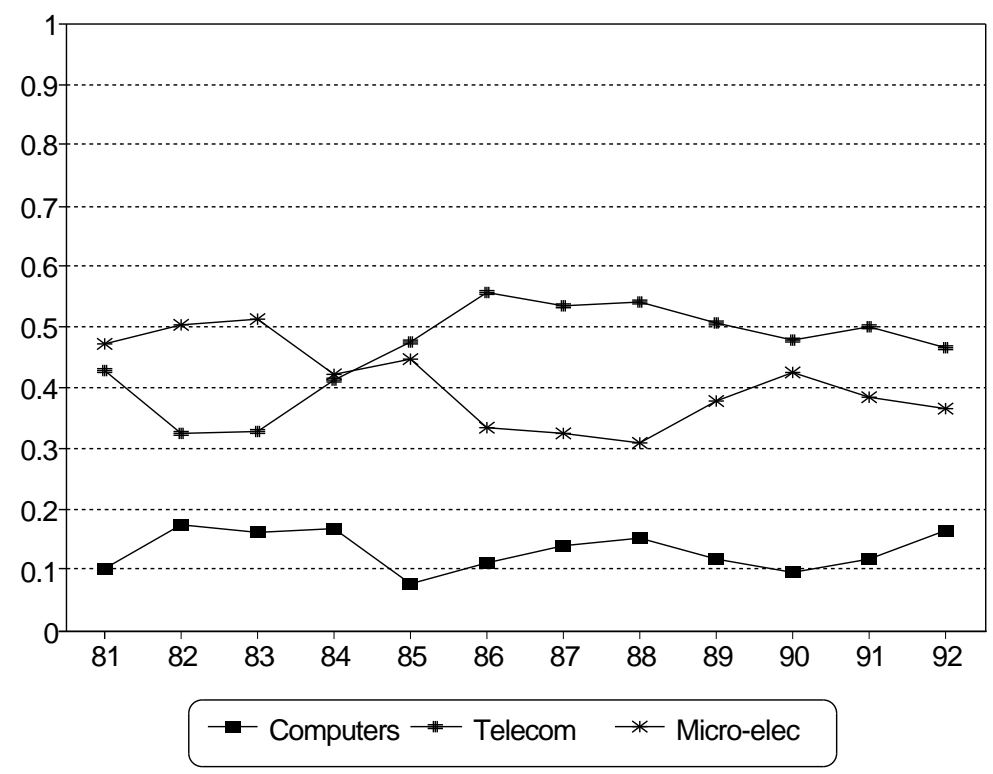


Table 1 Results of the regression analysis on alliances and patents of major computer companies.

\begin{tabular}{|c|c|c|c|c|c|c|c|c|}
\hline & B & SE B & $\mathrm{T}$ & $\operatorname{sig} \mathrm{T}$ & $\mathrm{R}^{2}$ & SE & F & Const \\
\hline \multicolumn{9}{|l|}{ Computers } \\
\hline Patents & 1.036 & 0.244 & 4.243 & 0.011 & 0.599 & 3.686 & $17.99^{*}$ & 29.040 \\
\hline Alliances & -0.171 & 0.698 & -0.245 & 0.811 & 0.005 & 10.538 & 0.060 & 33.729 \\
\hline \multicolumn{9}{|l|}{ Telecom } \\
\hline Patents & -0.191 & 0.288 & -0.664 & 0.519 & 0.035 & 4.346 & 0.441 & 42.750 \\
\hline Alliances & -0.171 & 0.699 & -0.245 & 0.811 & 0.005 & 10.536 & 0.060 & 33.729 \\
\hline \multicolumn{9}{|l|}{ Micro-elec. } \\
\hline Patents & -0.845 & 0.193 & -4.380 & 0.001 & 0.615 & 2.911 & $19.18^{*}$ & 28.206 \\
\hline Alliances & 0.330 & 0.790 & 0.417 & 0.684 & 0.014 & 11.919 & 0.174 & 36.380 \\
\hline
\end{tabular}

${ }^{*} \mathrm{p}<0.01$.

Table 2 Results of the regression analysis on alliances and patents of major telecommunications equipment companies.

B SEB T $\quad$ sig $T R^{2} \quad S E \quad F \quad$ Const

$\begin{array}{lllllllll}\text { Computers } & & & & & & & & \\ \text { Patents } & 0.291 & 0.180 & 1.618 & 0.132 & 0.179 & 2.717 & 2.617 & 15.015 \\ \text { Alliances } & 0.266 & 0.534 & 0.498 & 0.628 & 0.020 & 8.048 & 0.248 & 11.616 \\ & & & & & & & & \\ \text { Telecom } & & & & & & & & \\ \text { Patents } & 0.431 & 0.198 & 2.171 & 0.050 & 0.282 & 2.992 & 4.712^{*} & 54.765 \\ \text { Alliances } & 0.752 & 0.724 & 1.039 & 0.319 & 0.083 & 10.918 & 1.080 & 40.633\end{array}$

Micro-elec.

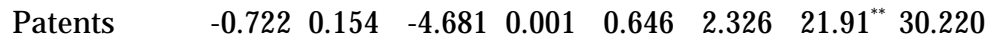

$\begin{array}{lllllllll}\text { Alliances } & -0.901 & 0.701 & -1.286 & 0.223 & 0.121 & 10.570 & 1.654 & 46.457\end{array}$ 


\section{References}

Acs. Z.J. and D.B. Audretsch (1989), 'Patents as a Measure of Innovative Activity', Kyklos, 4: 171-180.

Aldrich, H.E., (1979), Organizations \& Environments, Prentice-Hall, Englewood Cliffs.

Aldrich, H. and E.R. Auster (1986), 'Even Dwarfs Started Small : Liabilities of Age, Size and their Strategic Implications', in B. Staw and L.L. Cummings, Research in Organizational Behavior, JAI Press, Greenwich, 8: 165-98.

Archibugi, D. (1992), 'Patenting as an Indicator of Technological Innovation: A Review', Science and Public Policy, 6: 357-358.

Charles, D., P. Monk and E. Sciberras (1989), Technology and Competition in the International Telecommunications Industry, Pinter Publishers, London.

Cohen, W.M and R.C. Levin (1989), 'Empirical Studies of Innovation and Market Structure', in R. Schmalensee and R.D. Willig, Handbook of Industrial Organization, Volume II, Elsevier Science Publishers, New York.

Cohen, W.M and D.A. Levinthal (1990), 'Absorptive Capacity: a New Perspective on Learning and Innovation', Administrative Science Quarterly, 35: 128-152.

Cyert, R.M. and J.G. March (1963), A Behavioral Theory of the Firm, Prentice-Hall, Englewood Cliffs.

Davies, A.C. (1991), 'The Digital Divide: A Political Economy of the Restructuring of Telecommunications', unpublished D.Phil. thesis, University of Sussex, Brighton.

Dodgson, M. (1989), Technology Strategy and the Firm, Management and Public Policy, Longman, London.

Dorfman, N.S. (1987), Innovation and Market Structure : Lessons from the Computer and Semiconductor Industries, Ballinger, Cambridge, Mass.

Dosi, G. (1988), 'Sources, Procedures, and Microeconomic Effects of Innovation', Journal of Economic Literature, 26: 1120-71.

Duysters, G. and J. Hagedoorn (1996), 'Internationalization of Corporate Technology through Strategic Partnering: An Empirical Investigation', Research Policy, forthcoming.

Economic Commission for Europe (1987), The Telecommunication Industry: Growth and Structural Change, United Nations, New York.

Georghiou, L., J.S. Metcalfe, M. Gibbons, T. Ray and J. Evans (1986), Post-Innovation Performance: Technological Development and Competition, Macmillan, New York. 
Griliches, Z. (1990), 'Patent Statistics as Economic Indicators: A Survey', Journal of Economic Literature, 28: 1661-797.

Hagedoorn, J. (1992), 'Strategic Alliances in Information Technology among Firms in Western Industrialized Nations', in L.S Peters (ed.), International Issues in the Management of Technology, Vol 10, JAI Series on International Business and Finance.

Haklisch, C.S. (1986), Technical Alliances in the Semiconductor Industry, unpublished manuscript, New York University.

Haklisch, C.S. (1989), 'Technical Alliances in the Semiconductor Industry: Effects on Corporate Strategy and R\&D', in Background Papers for Conference on Changing Global Patterns of Industrial Research and Development, Stockholm, 20-22 June.

Harper, J.M. (1986), Telecommunications and Computing the Uncompleted Revolution, Communications Educational Services, London.

Lant, T.K. and S.J. Mezias (1992), 'An Organizational Learning Model of Convergence and Reorientation', Organization Science, 3: 47-71.

Leban, R., J. Lesourne, K. Oshima and T. Yakushiji (1989), Europe and Japan Facing High Technologies, Economica, Paris.

Levinthal, D.A. (1994), 'Surviving Schumpeterian Environments: An Evolutionary Perspective', in J.A.C. Baum and J.V. Singh (eds), Evolutionary Dynamics of Organizations, Oxford University Press, New York.

Malerba, F., S. Torrisi and N. von Tunzelmann (1991), 'Electronic Computers', in C. Freeman, M. Sharp and W. Walker (eds.), Technology and the Future of Europe: Global Competition and the Environment in the 1990s, Pinter Publishers, London.

Mansell, R. (1993), The New Telecommunications: A Political Economy of Network Evolution, Sage Publications, Newbury Park, London.

McKelvey, B. (1982), Organizational Systematics, University of California Press, Berkeley.

Nelson, R.R. (1987), Understanding Technical Change as an Evolutionary Process, Elsevier Science Publishers, New York.

Nelson, R.R. and S.G. Winter (1982), An Evolutionary Theory of Economic Change, Belknap Press, Cambridge, Mass.

Nystrom, H. and B. Edvardsson (1980), 'Research and Development Strategies for Swedish Companies in the Farm Machinery Industry', in D. Sahal, Research, Development, and Technological Innovation, Lexington Books, Lexington, Mass. 
Pavitt, K. (1988), 'Uses and Abuses of Patent Statistics', in A.F.J. van Raan, Handbook of Quantitative Studies of Science and Technology, Elsevier, Amsterdam.

Raphael, D.E. (1989), The Changing Structure of the Global Information Industry, SRI International, Report No. 807.

Starbuck, W.H., A. Greve and B.L.T. Hedberg (1978), 'Responding to Crisis', Journal of Business Administration, 9: 111-37.

Stinchcombe, A.L. (1965), 'Social Structure and Organizations', in J.G. March (ed.), Handbook of Organizations, Rand McNally, Chicago.

Tunstall, J. (1986), Communications Deregulation: The Unleashing of America's Communications Industry, Basic Blackwell, Oxford.

van Tulder, R. and G. Junne (1988), European Multinationals in Core Technologies, John Wiley \& Sons, Chichester.

von Tunzelmann, N. (1988), 'Convergence of Firms in Information and Communication: A Test using Patents Data', mimeo, Science Policy Research Unit, Brighton.

von Tunzelmann, N. and L. Soete, (1987), Diffusion and Market Structure with Converging Technologies, Research Memorandum, University of Limburg, Maastricht. 


\section{NOTES}

1. The introduction of stored program control (SPC) in electronic switches made it possible to replace mechanical control systems by much more flexible software-based control programs.

2.In this paper the term 'core competencies' is used to describe the traditional focus of the companies in our analysis.

3. Harper (1986) observed that in the early 1980s only a very limited number of products embodied both communications and computing functions.

4. As semiconductor companies are vertically and not horizontally related to the other IT industries we cannot test both hypotheses on these companies, as these hypotheses relate primarily to 'lateral entry'.. Semiconductor companies are affected by the convergence process basically by a change in the degree of diffusion of their components in the end products of the computer and telecommunications industry.

5. The full list of companies which are analysed in this paper can be found in Appendix I.

6. We assume that alliances between government or academic institutions and private companies are often less profit seeking and are to a lesser extent used for product development.

7. For a further analysis of structural and strategic differences among companies from various home countries, see Duysters and Hagedoorn (1996). 